\title{
The Diabetic Chinese Hamster: In Vitro Insulin and Glucagon Release; The "Chemical Diabetic"; and the Effect of Diet on Ketonuria
}

\author{
G.M. Grodsky, B.J. Frankel, J.E. Gerich, and G.C. Gerritsen \\ Metabolic Research Unit, Department of Biochemistry and Biophysics, University of California, San Francisco, \\ California 94143, USA and The Upjohn Company, Kalamazoo, Michigan, USA
}

\begin{abstract}
Summary. Insulin and glucagon release (in response to glucose, theophylline, and arginine) were measured from the in vitro perfused pancreases of non-ketotic diabetic Chinese hamsters. These animals showed impaired alpha and beta cell sensitivity to glucose (i. e. excessive glucagon, and a reduction in both phases of insulin release) and abnormal alpha cell sensitivity to arginine (excessive glucagon), but normal responses to theophylline. Pancreatic insulin content was significantly decreased and glucagon content increased in unperfused diabetic pancreases. Abnormal responses to glucose and arginine were not directly related to pancreatic content, since responses to theophylline were normal. Insulin responses of normal animals from five normal sublines and non-ketotics from eight diabetic sublines were compared; certain diabetic sublines showed significantly less insulin release than did others, despite similar severities of glucosuria. -
\end{abstract}

Fasting blood glucose during stress, glucose tolerance, and in vitro pancreatic insulin responses to glucose were measured in the normoglycemic, aglucosuric siblings of diabetics; the responses were diabetic-like, and therefore such animals are referred to here as "chemical diabeties". - The incidence of glucosuria and ketonuria was studied in ketotic diabetic hamsters on high-and low-fat diets; glucosuria decreased and ketonuria disappeared on the low-fat diet.

Key words: Insulin secretion, glucagon secretion, Chinese hamster, glucose, arginine, theophylline, subline variation, chemical diabetic, latent diabetic, high-fat diet, effect of diet, glucose tolerance test, pancreatic insulin content, pancreatic glucagon content, perfused hamster pancreas.
This manuscript summarizes our studies of insulin and glucagon secretion from the in vitro perfused pancreases of non-ketotic, genetically diabetic Chinese hamsters $[1,2]$ whose abnormal alpha and beta cell sensitivities to glucose and arginine are similar to those reported for human diabetes [3]. Since the relationship between pancreatic hormone content and the pattern of hormone release is not well characterized in the Chinese hamster or man, we now interrelate the insulin and glucagon content of unperfused pancreases from diabetic and normal Chinese hamsters.

Despite a high degree of inbreeding, diabetic Chinese hamsters vary greatly in the incidence and severity of their disease [4]. To evaluate variation within sublines and the possibility that sublines of apparently similar diabetic severity may differ in their capacity to secrete insulin, we have also compared in vitro pancreatic insulin responses to glucose of 61 animals from five normal and eight diabetic sublines.

While studying in vitro pancreatic insulin responses of presumably normal hamsters, we noted an unusual spread in the data. After careful examination of the genetic backgrounds of the animals, we found that five of the animals had come from diabetic sublines and had diabetic siblings and parents. Although inbred with, and genetically similar to, their diabetic siblings, such apparently normal animals remain normoglycemic and show no glucosuria or ketonuria after about five months of age [5]. These animals have often been assumed to be "normal" and have been used as controls in various studies. To further characterize these animals, our studies included measurement of blood glucose levels during stress, glucose tolerance tests, and in vitro pancreatic insulin responses to glucose. The results indicate that such apparently "normal" animals more closely resemble their diabetic siblings than normal animals that have no genetic diabetic background. Therefore, we refer to them as "chemical diabetics" to correspond to the "chemical" or "latent" "subclinical diabetic" classification applied to certain human diabetics [6].

The most severely affected diabetic hamsters, ketotic diabetics, show relatively constant ketonuria throughout their diabetic lives and have a strong genetic diabetic background [7]. Surprisingly, ketotic animals shipped to San Francisco became nonketonuric. Evaluation of the diet showed that dietary changes strongly influence the manifestation of diabetes (incidence and severity of glucosuria and ketonuria) in these animals.

\section{Materials and Methods}

Adult, normal and diabetic Chinese hamsters of both sexes were obtained from the Upjohn Company, Kalamazoo, Michigan, through the courtesy of Drs. George C. Gerritsen and William E. Dulin. Normal animals came from sublines that had been inbred for lack of diabetic symptoms and had shown no glucosuria for at least five generations. Animals with diabetes 
of varying severity were defined for the purposes of this study as follows: "Chemical diabetics", siblings of diabetic animals, had normal fasting blood glucose levels at Upjohn, and had shown no glucosuria when tested every two weeks since weaning; "Non-ketotic diabetics" had shown consistent glucosuria but no ketonuria; and "Ketotic diabetics" had shown glucosuria and ketonuria. At Upjohn, animals received Purina Mouse Chow (Ralston Purina Co., St. Louis, Mo.) containing approximately $11 \%$ fat, $17 \%$ protein, and $53 \%$ carbohydrate (the "hi-fat" diet).

After arrival in California, animals were fed Berkeley Standard Diet Rat and Mouse Chow (Feedstuffs Processing Co., San Francisco) containing approximately $4 \%$ fat, $23 \%$ protein, and $54 \%$ carbohydrate (the "Io-fat diet").

\section{Results}

\section{Non-Ketotic Diabetic Hamsters}

As recently shown [1], infusion of glucose $(300$ $\mathrm{mg} / 100 \mathrm{ml}$ ) caused the characteristic biphasic insulin release $[8,9]$ from the in vitro perfused pancreases of normal Chinese hamsters (Fig. 1). Despite considerable variation, pancreases from non-ketotic diabetic hamsters secreted significantly $(p=0.015)$ less insulin than did normals. Both phases of insulin release in the diabetics were inhibited to a similar extent $(50-55 \%$ of normal). In the diabetic perfusion experiments, glucose-stimulated insulin release did not correlate with age, body weight, fasting blood sugar at laparotomy, or duration of diabetes; however, it did correlate with mean urine sugar during life [1].

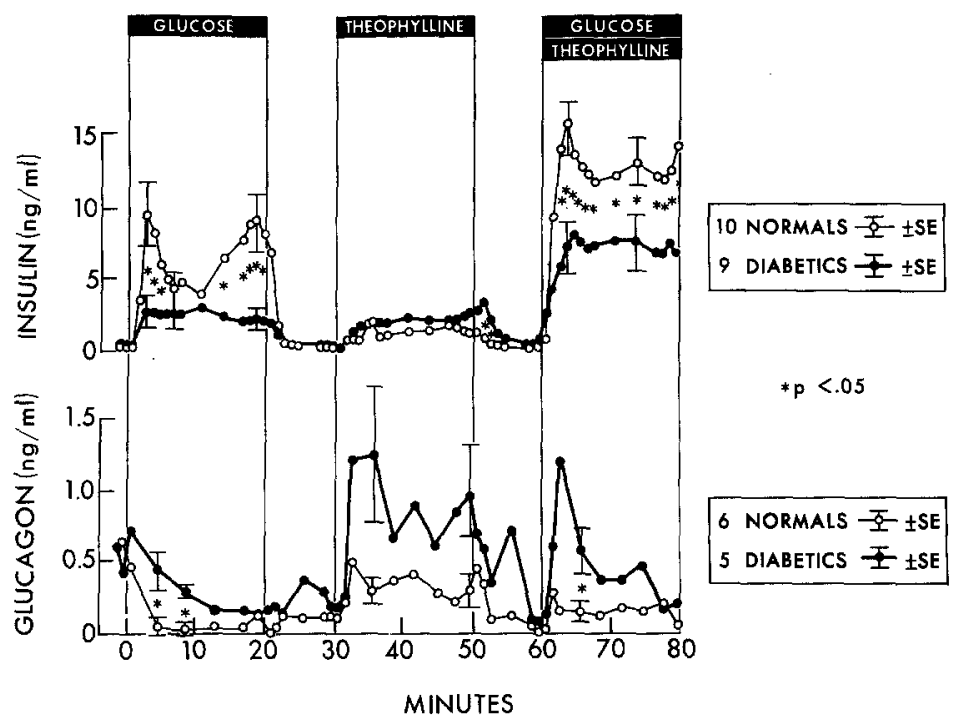

Fig. 1. Mean ( $\pm \mathrm{SE}$ ) insulin and glucagon responses of normal (O) and non-ketotic diabetic (†) Chinese hamster pancreases to $20 \mathrm{~min}$ infusions of glucose $(300 \mathrm{mg} / 100 \mathrm{ml})$, theophylline $(10 \mathrm{mM})$, and glucose $(300 \mathrm{mg} / 100 \mathrm{ml}) \mathrm{plus}$ theophylline $(10 \mathrm{mM})$. Figure taken from Ref. 1

Food pellets were removed from cages about $18 \mathrm{~h}$ before all studies. Blood for glucose determination (Dextrostix and the Ames Reflectance Meter [Ames Co., Division Miles Labs., Inc., Elkhart, Indiana]) was drawn from the abdominal vena cava or aorta under sodium pentobarbital anesthesia (Diabutal; Diamond Labs., Des Moines, Iowa) prior to perfusion experiments, and from the orbital sinus under methoxyflurane anesthesia (Metofane; PitmanMoore, Inc, N.J.) during the intraperitoneal glucose $(1 \mathrm{~g} / \mathrm{kg})$ tolerance tests. The technique of pancreatic perfusion and the immunoassay of insulin and glucagon have been described previously [1].

Two-sided, unpaired (Student $t$ ) analysis was used to analyze all data.
Basal secretion of glucagon (Fig. 1) was the same from the normal and diabetic groups. Glucose suppressed glucagon release $90 \%$ in the normals within $10 \mathrm{~min}$; suppression in the diabetics was slower and of less magnitude, resulting in significantly greater glucagon secretion during this experimental period.

To establish that the differential effects of glucose on hormone release from normal and diabetic pancreases were not characteristic of all stimulating agents, we studied the effects of theophylline on insulin and glucagon release. Ten $\mathrm{mM}$ theophylline (in the absence of glucose) stimulated both insulin and glucagon release (Fig. 1). Although mean glucagon secretion from the diabetic pancreases was greater than normal, this difference was not significant. Additional ex- 
periments with theophylline alone as the initial stimulant [1, 2] clearly showed that theophyllineinduced insulin and glucagon secretion were the same from normal and diabetic pancreases.

When theophylline and glucose were combined, insulin secretion was enhanced in the diabetics to a level similar to that seen in normals in response to glucose alone (Fig. 1). However, the response to the same combined stimulus of diabetic pancreases was still significantly less than that of normals. Despite the large amounts of insulin secreted, suppression of glucagon by glucose plus theophylline was still impaired in the diabetics.
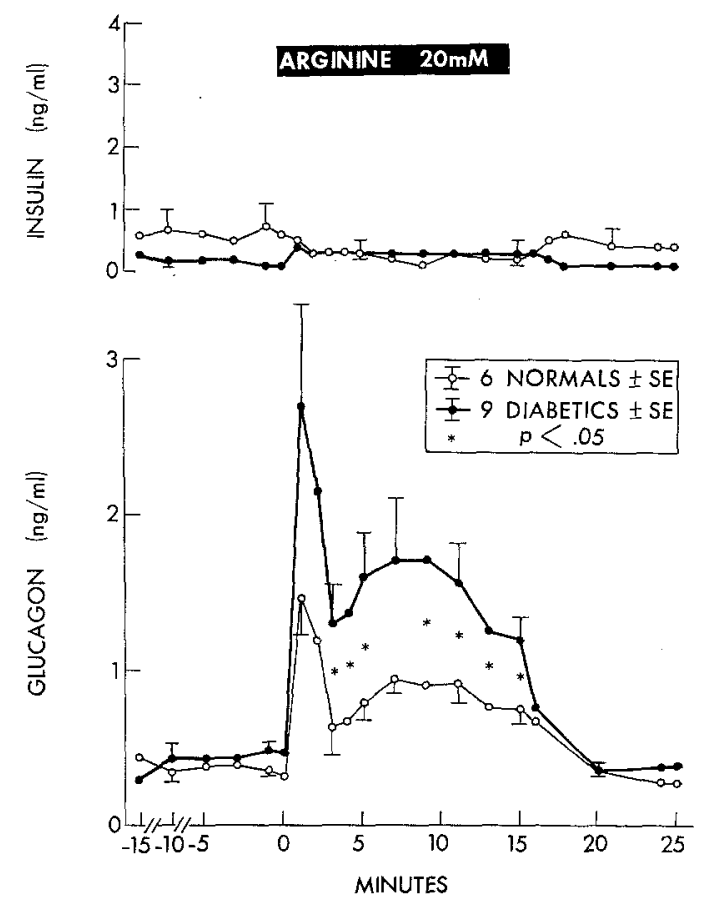

Fig. 2. Mean ( $\pm \mathrm{SE}$ ) insulin and glucagon responses of normal $(O)$ and non-ketotic diabetic $(\bullet)$ Chinese hamster pancreases to $15 \mathrm{~min}$ infusion of arginine $(20 \mathrm{mM})$

Arginine $(20 \mathrm{mM})$, in the absence of glucose, caused biphasic glucagon secretion with little or no insulin release from both normal and diabetic pancreases (Fig. 2). Although insulin release from diabetic and normal pancreases was similar and almost undetectable, arginine-stimulated glucagon release was signif. icantly greater in the diabetic pancreases.

Pancreatic insulin and glucagon contents of unperfused pancreases from five normal and five non-ketotic diabetic hamsters were determined (Table 1). Insulin content of diabetic pancreases was significantly less than normal $(-39 \% ; p=0.011)$; glucagon content was significantly greater than normal $(+33 \%$; $p=0.052$ ).

We previously noticed a large variation in responses from the perfused pancreases of Chinese hamsters [1]; similar variations in other metabolic parameters have also been noted [10]. The possibility that this pancreatic variation may reflect genetic differences between sublines was examined, at least in a preliminary fashion, by relating in vitro insulin secretion to subline in 27 normal and 34 non-ketotic diabetic pancreas perfusions. Since the scarcity of diabetic Chinese hamsters did not permit their use solely for subline studies, data were drawn from a variety of previous studies $[1,2]$ and normalized by calculating the insulin response to glucose from each pancreas as a percent of the mean normal response in the same study (Fig. 3). Both normals and diabetics within each subline showed a wide range of responses,

Table 1. Insulin and Glucagon content of un-perfused pancreases

\begin{tabular}{lll}
\hline & $\begin{array}{l}\text { Insulin } \\
(\mu g / g \text { wet wt) }\end{array}$ & $\begin{array}{l}\text { Glucagon } \\
(\mu g / g \text { wet wt) }\end{array}$ \\
\hline Normals & & \\
\hline 1 & 25.77 & 3.196 \\
2 & 45.23 & 3.478 \\
3 & 27.80 & 2.066 \\
4 & 35.45 & 3.435 \\
5 & 39.84 & 3.080 \\
$\overline{\bar{X}}(5)$ & 34.82 & 3.051 \\
SE & 3.64 & 0.257 \\
\hline Diabetics & & \\
\hline 1 & 23.86 & 5.168 \\
2 & 24.04 & 3.578 \\
3 & 14.08 & 3.067 \\
4 & 22.13 & 4.288 \\
5 & 22.29 & 4.155 \\
$\overline{\bar{X}}(5)$ & 21.28 & 4.051 \\
SE & 1.84 & 0.354 \\
$p=$ & 0.011 & 0.052 \\
\hline
\end{tabular}

and not all sublines are yet adequately represented. However, diabetic sublines $\mathrm{X}$ and $\mathrm{XA}$ were well represented ( $n=8, n=7)$, and their insulin responses were consistently low, the mean being only 27 and $44 \%$ of the normal. Diabetic subline $\mathrm{X}$ showed a significantly lower mean insulin release than did diabetic subline $Z(p=0.017)$. Gerritsen [11] has suggested that these two highly inbred sublines may have different genetic bases of diabetes, since first generation hybrids fail to show diabetes.

\section{"Normal" Aglucosuric Chinese Hamsters from Diabetic Sublines}

Fasting blood glucose levels during stress of laparotomy of 9 normal, 4 "chemical diabetic", and 11 non-ketotic diabetic hamsters are shown in Fig. 4. Compared with the normal animals, the non-ketotic diabetics were significantly hyperglycemic $(p<0.0001)$. Although one of the "chemical diabetics" had a blood glucose level well within the normal range, the mean level of the group was significantly greater than the normal ( $p=0.039$ ) and less than that of the overtly diabetic animals $(p=0.057)$. 
As part of a related study [12], 30-min intraperitoneal glucose tolerance tests were performed on 24 fasting "chemical diabetics" and 24 normal hamsters (Fig. 5). The individual fasting blood glucose levels $(0)$ varied greatly in both normals and diabetics. The "chemical diabetics" mean ( \pm SE) fasting level $(105 \pm 5)$ was greater than the normals' $(95 \pm 2 ; p=$ $0.054)$, but this difference was small and there was considerable overlap of the individual values. The mean blood glucose level $30 \mathrm{~min}$ after glucose administration was significantly greater $(p=0.002)$ in the "chemical diabetics" than in the normals, though again there was a considerable overlap.

Mean in vitro pancreatic insulin responses to glucose $(300 \mathrm{mg} / 100 \mathrm{ml})$ of 5 chemical diabetics are compared with the mean responses of 11 normal and of 17 non-ketotic diabetic pancreases in Fig. 6. Both first and second phase insulin release by the "chemical

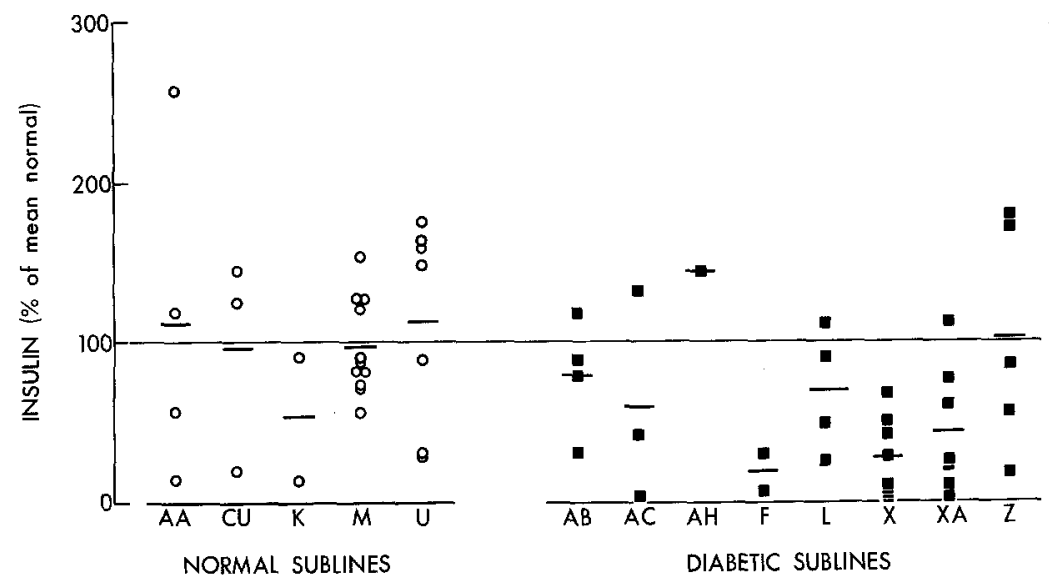

Fig. 3. Comparison of pancreatic insulin responses to glucose of normal animals from five normal sublines and non-ketotic animals from eight diabetic sublines as a percent of the mean normal response (the horizontal line at $100 \%$. Individual, short horizontal bars represent the mean response of each subline

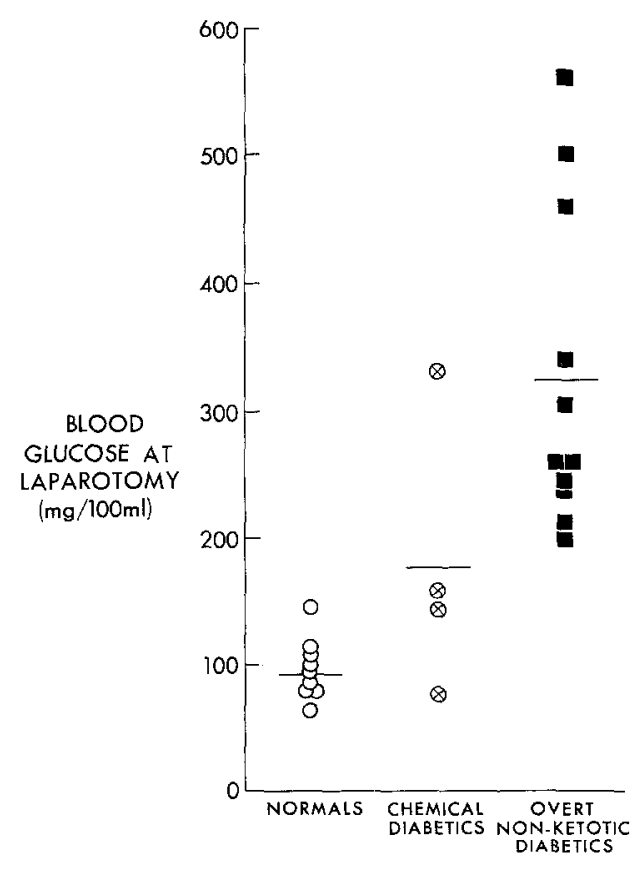

Fig. 4. Fasting blood glucose at laparotomy in normal (O) chemical diabetic $(\otimes)$, and overtly (non-ketotic) diabetic (ש) Chinese hamsters. Short horizontal bars represent ivean blood glucose levels. Data for normals and nonketotics taken from Ref. 1 diabetics" were diminished (41 and $54 \%$ of normal); the "chemical diabetics" pattern of insulin release much more closely resembled the release by their non-ketotic diabetic siblings than the release by aglucosuric animals with no diabetic heritage. It is of interest that the "chemical diabetic" with the normal blood sugar $(78 \mathrm{mg} / 100 \mathrm{ml}$ ) had the most "normal" (highest) insulin response.

\section{Ketotic Diabetic Hamsters}

Six hamsters that had shown glucosuria and ketonuria at the Upjohn colony in Michigan on the "Purina diet" were shipped to California and fed the "Berkeley diet". All six animals had shown intermittent ketonuria for months, and five were ketonuric immediately before shipment (Fig. 7; Table 2). After six weeks in California on the "Berkeley diet", none of the animals showed ketonuria. When the original diet was reinstated, four of the six animals again showed ketonuria. Glucosuria also decreased during the "Berkeley diet" and increased on reinstatement of the "Purina diet". As shown in Fig. 7, the "Berkeley diet" differed from the "Purina diet" in that it contained only one-third as much fat and more protein; the carbohydrate contents were identical.

\section{Discussion}

The non-ketotic, diabetic Chinese hamster is an important model for studying the pathogenesis of a 
genetic diabetic syndrome resembling that occurring in non-obese, insulin-deficient humans. This hamster is non-obese, in contrast to other genetically diabetic animals [13]. Although ketotic hamsters go through a hyperphagic period soon after birth [11], it is not known if non-ketotic animals also go through such a stage.

Recent studies have suggested that both phases of glucose-stimulated insulin release may be initiated one of the two phases. As in human diabetes, the pancreatic alpha cell also appears to be insensitive to glucose: glucose was a less effective suppressant of glucagon release in the diabetic pancreases than in the normals.

Extracted insulin was significantly lower and extracted glucagon higher in the diabetic pancreases, consistent with previous suggestions based on histo-

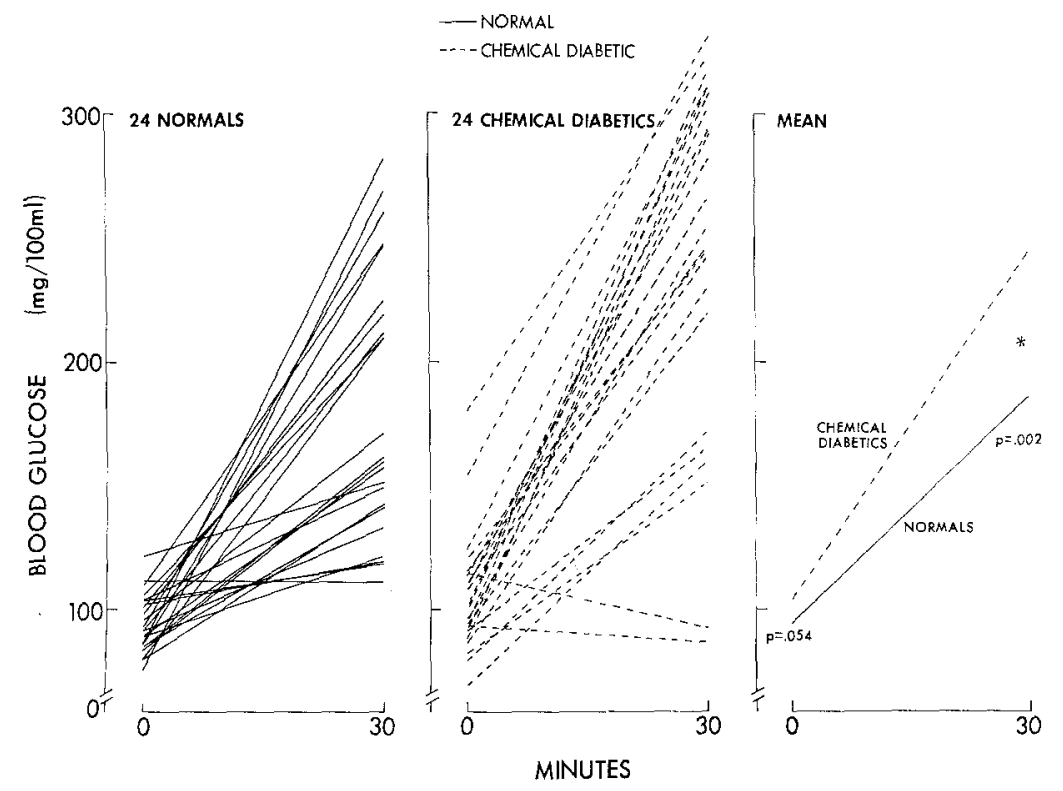

Fig. 5. Glucose tolerance tests in normal (-) and chemical diabetic (-) Chinese hamsters

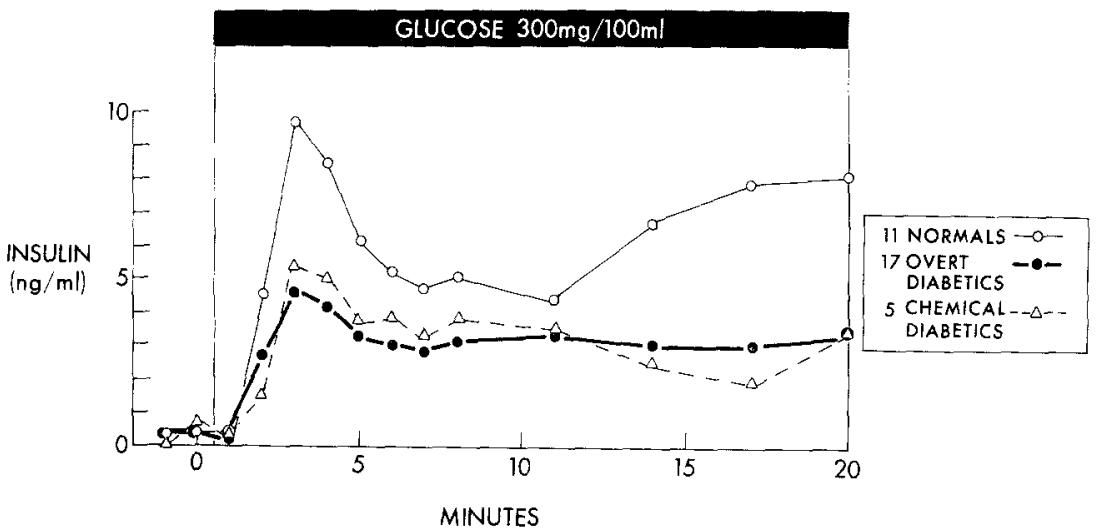

Fig. 6. Mean insulin responses of normal (O), chemical diabetic $(\Delta)$, and non-ketotic diabetic (๑) Chinese hamster pancreases to $20 \mathrm{~min}$ infusion of glucose $(300 \mathrm{mg} / 100 \mathrm{ml})$. Data for normals and non-ketotics taken from Ref. 1

by a common glucose signal since, in normal rats [9] and in man [14], the glucose $K_{m}$ for the first and second phases is the same. In our diabetic hamster pancreases, as in man [14], both phases of insulin release were impaired to a similar extent, suggesting an early defect in glucose action on the beta cell (possibly involving a glucoreceptor) rather than a preferential defect in a specific phenomenon underlying logic examination [15]. The lower insulin and higher glucagon reserves could have contributed to the decreased insulin and increased glucagon secretion in response to glucose in our perfusion experiments. This is probably not the major factor, however, since: 1. the secretion defect appeared relatively specific for glucose and arginine, theophylline stimulating both insulin and glucagon release identically in both 
normals and diabetics; 2 . basal hormone release in both normals and diabetics was the same; and 3 . no correlation existed between in vitro hormone secretion and pancreatic content (after perfusion) among individual animals in either the normal or diabetic groups $[1,2]$.

The identical results with theophylline in the normal and diabetic hamsters suggest that the cyclic also hyperresponded to arginine, even in the absence of added glucose, indicating an alpha cell hypersensitivity to arginine that may be unrelated to the insensitivity to glucose.

Studies in the alloxanized dog have indicated that suppression of glucagon secretion from the alpha cell by glucose may be insulin-requiring [17]. In the experiments reported here, the diabetics' glucagon

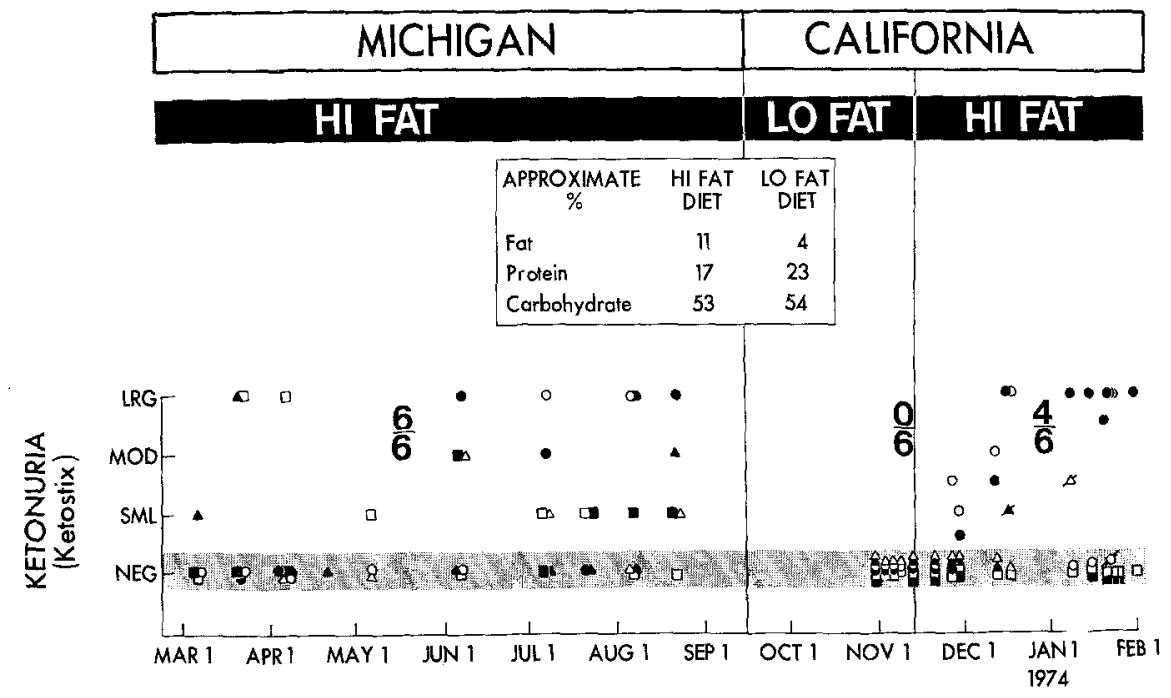

Fig. 7. Incidence of ketonuria in 6 "ketotic" Chinese hamsters on hi-fat, then lo-fat, then hi-fat diet. Slash mark through symbol $(\boldsymbol{\Lambda}, \mathcal{A}, \sigma)$ indicates last measurement before death. Shaded area represents no measurable ketonuria

Table 2. Incidence of glucosuria and ketonuria in 6 "ketotics" on two diets

\begin{tabular}{|c|c|c|c|c|c|c|c|c|c|c|}
\hline \multirow[t]{2}{*}{ No. } & \multirow[t]{2}{*}{ Subline } & \multirow[t]{2}{*}{$\begin{array}{l}\text { Gener- } \\
\text { ation }\end{array}$} & \multirow[t]{2}{*}{ Sex } & \multirow{2}{*}{$\begin{array}{l}\text { Age at } \\
\text { switch from } \\
\text { hi-fat to } \\
\text { lo-fat diet } \\
\text { (mo.) }\end{array}$} & \multicolumn{3}{|c|}{$\begin{array}{l}\text { Glucosuria } \\
\text { Trace or greater/ } \\
\text { no. of measurements }\end{array}$} & \multicolumn{3}{|c|}{$\begin{array}{l}\text { Ketonuria } \\
\text { Trace or greater/ } \\
\text { no. of measurements }\end{array}$} \\
\hline & & & & & $\begin{array}{l}(6 \mathrm{mo}) \\
\text { hi-fat }\end{array}$ & $\begin{array}{l}(2 \mathrm{mo}) \\
\text { lo-fat }\end{array}$ & $\begin{array}{l}(21 / 2 \mathrm{mo} .) \\
\text { hi-fat }\end{array}$ & $\begin{array}{c}(6 \text { mo.) } \\
\text { hi-fata }\end{array}$ & $\begin{array}{l}(2 \text { mo. }) \\
\text { lo-fat }\end{array}$ & $\begin{array}{l}(21 / 2 \text { mo. }) \\
\text { hi-fat } \\
\end{array}$ \\
\hline $\begin{array}{l}1 \\
2 \\
3 \\
4 \\
5 \\
6\end{array}$ & $\begin{array}{l}\mathrm{AC} \\
\mathrm{AH} \\
\mathrm{F} \\
\mathrm{L} \\
\mathrm{AB} \\
\mathrm{F}\end{array}$ & $\begin{array}{r}7 \\
8 \\
9 \\
21 \\
8 \\
9\end{array}$ & $\begin{array}{l}\mathrm{M} \\
\mathrm{M} \\
\mathrm{M} \\
\mathrm{F} \\
\mathrm{F} \\
\mathrm{M}\end{array}$ & $\begin{array}{r}16.6 \\
9.0 \\
18.4 \\
16.1 \\
15.4 \\
18.4\end{array}$ & $\begin{array}{l}7 / 8 \\
6 / 6 \\
7 / 7 \\
7 / 7 \\
9 / 9 \\
9 / 9\end{array}$ & $\begin{array}{l}1 / 2 \\
5 / 5 \\
6 / 6 \\
4 / 4 \\
2 / 2 \\
0 / 5\end{array}$ & $\begin{array}{c}5 / 8 \\
6 / 6 \\
8 / 8 \\
12 / 12 \\
5 / 5 \\
5 / 12\end{array}$ & $\begin{array}{l}4 / 8 \\
3 / 6 \\
2 / 7 \\
4 / 7 \\
3 / 9 \\
5 / 9\end{array}$ & $\begin{array}{l}0 / 2 \\
0 / 5 \\
0 / 6 \\
0 / 4 \\
0 / 2 \\
0 / 5\end{array}$ & $\begin{array}{c}0 / 7 \\
1 / 6 \\
4 / 8 \\
10 / 12 \\
1 / 5 \\
0 / 12\end{array}$ \\
\hline$\overline{\mathrm{X}}(6)$ & & 10 & & $\begin{array}{r}15.7 \\
1.4\end{array}$ & $(0.97)$ & $(0.75)$ & $(0.80)$ & $(0.45)$ & $(0.00)$ & $(0.33)$ \\
\hline
\end{tabular}

a From Upjohn records; urinalysis attempted every two weeks.

AMP systems in the beta and alpha cells of the diabetic are normal. As shown in human diabetics [16], this diesterase inhibitor partially "normalized" insulin secretion. However, in these in vitro studies, sensitivity to glucose was not restored; the diabetics still secreted significantly less insulin than did the normals when subjected to glucose and theophylline together.

Arginine causes hypersecretion of glucagon in human diabetics [3]. The diabetic hamster alpha cell release was elevated during combined glucose and theophylline stimulation, even though insulin release was as high as that obtained in normals stimulated with a high concentration of glucose. In addition, excessive glucagon release was observed in the diabetic pancreases during stimulation by arginine alone. During this time insulin release was marginal and not different in normal diabetics. Thus, abnormal glucagon secretion from the genetically diabetic hamster pancreas does not appear to be secondary to the lack 
of insulin per se. Rather, the abnormal glucagon secretion closely resembles human diabetes and appears to result from abnormal alpha cell sensitivities to glucose [18] and to arginine. Whether or not the abnormal sensivities are the result of prolonged hypoinsulinism during life cannot be ascertained from these acute, in vitro studies.

Several sublines of Chinese hamsters have been brother-sister inbred for ten or more generations and are therefore theoretically more than $90 \%$ genetically homozygous [19]. That these animals are not phenotypically identical, as far as the severity of their diabetes, would suggest a contribution by environmental factors or a complicated genetic expression. Although not all of our non-ketotic diabetic animals were inbred for ten or more generations, their diabetes was of similar severity. Still, insulin secretion varied widely, even within specific sublines. Some sublines were consistently low insulin secretors (yet were no more glucosuric than others). This suggests that decreased insulin release is not the sole cause for the glucosuria of genetic diabetes. Gerritsen et al. [11] have reported preliminary evidence that two highly purified diabetic sublines $(X \& Z)$ do not produce diabetics when intermated, suggesting that each subline carries different forms of genetic diabetes. Fortuitously, a large enough number of animals from these sublines was included in our studies and revealed that the $X$ subline secretes significantly less insulin than the $Z$ subline, supporting the suggestion that there is a biochemical difference between the two diabetic forms. As often suspected, diabetes mellitus in man may also be a collection of several genetically different, but phenotypically similar diseases.

Despite the high degree of genetic purity in some diabetic sublines, $20 \%$ of the animals have normal blood sugars and no glycosuria. Our studies indicate that these "chemical diabetic" animals are not normal. They showed: 1. an elevated fasting blood glucose during surgical stress, compared with animals from normal sublines; 2 . statistically abnormal fasting blood glucose and glucose tolerance (however, the overlap with the normals was great); and 3. a pattern of pancreatic insulin release, stimulated by glucose in vitro, more closely resembling that of the nonketotic diabetics than that of the normals.

The onset of diabetes occurs up to five or six months of age; after that time, those siblings of diabetics that are normoglycemic and aglucosuric remain so [5]. This suggests that some environmental insult may occur early in the development of overt diabetes and that chemical diabetics are those animals that had been spared this injury. Assuming parallelism in man, these observations suggest that the difference between the human "chemical diabetic" and overt diabetic may be more environmental than genetic, and that progression from chemical to overt diabetes is not the predicted result simply of abnormal genetics and ageing. Fajans $[6,20]$ has also noted that a surprisingly large number of human chemical diabetics remain stable for years.

In previous animal studies, these normoglycemic chemical diabetics were considered to be normal and were used as normal controls $[5,21]$. It is now apparent that they may be more useful as examples of animals with a stable genetic predisposition to diabetes and can be used in studies where the role of environmental factors superimposed on diabetic geneties is considered. Butler assumed that aglucosuric animals were genetically normal and estimated that four recessive genes are involved in the diabetes of the Chinese hamster [7]. Re-evaluation with these animals included in the diabetic group might suggest a simpler inheritance pattern for Chinese hamster diabetes.

Our preliminary studies with the ketotic diabetic hamsters show that a change of environment or diet or both can ameliorate glucosuria and ketonuria, and that these could be partially increased by reinstitution of the original diet. Although the change in fat content of the diet is implicated, the comparative influence of changes in protein, palatability, total consumption, etc. must be evaluated. A low-fat diet may facilitate prolonged remission in these animals, permitting decreased mortality in the colonies, easier distribution to investigators, and possible extension of our knowledge regarding chronic and acute dietary influences on severe genetic diabetes.

Acknowledgments. We wish to thank the Upjohn Company (Drs. George C. Gerritsen and William E. Dulin), Kalamazoo, Mich., for generously supplying the hamsters. Drs. M. Mozen and J. Lundblad of Cutter Laboratories, Berkeley, Calif., and James B. Lesh of The Armour Pharmaceutical Company, Kankakee, nl., generously supplied the albumin necessary for these studies.

We also wish to thank Mr. Rudy Fanska, Miss Gail Gustafson, Mrs. Mary Ann Jones, Miss Michele Manning, and Miss Florence Schmid for their excellent technical assistance.

This work was supported in part by Grant AM-01410 from The National Institutes of Arthritis and Metabolic Diseases, and by grants from the Hoechst Pharmaceutical Company, Somerville, N.J., The Upjohn Company, Kalamazoo, Mich., The Kroc Foundation, Santa Ynez, Calif. and The Levi J. and Mary C. Skaggs Foundation, Oakland, Calif.

\section{References}

1. Frankel, B.J., Gerich, J.E., Hagura, R., Fanska, R.E., Gerritsen, G.C., Grodsky, G.M.: Abnormal secretion of insulin and glucagon by the in vitro perfused pancreas of the genetically diabetic Chinese hamster. J. clin. Invest. 53, 1631-1646 (1974)

2. Frankel, B.J., Gerich, J.E., Fanska, R.E., Gerritsen, G.C., Grodsky, G.M.: Responses to arginine of the perfused pancreas of the genetically diabetic Chinese hamster. (In press)

3. Unger, R.H., Aguilar-Parada, E., Müller, W.A., Eisentraut, A.M.: Studies of pancreatic alpha cell function in normal and diabetic subjects. J. clin. Invest. 49, 837-848 (1970) 
4. Dulin, W.E., Gerritsen, G.C.: Interaction of genetics and environment on diabetes in the Chinese hamster as compared with human and other diabetic animal species. Acta diabet. lat. 9 (Suppl. 1), 48-84 (1972)

5. Schmidt, F.L., Leslie, L.G., Schultz, J.R., Gerritsen, G.C.: Epidemiological studies of the Chinese hamster. Diabetologia 6, 154-157 (1970)

6. Fajans, S.S.: The definition of chemical diabetes. Metabolism 22, 211-217 (1973)

7. Butler, L.: The inheritance of diabetes in the Chinese hamster. Diabetologia 3, 124-129 (1967)

8. Curry, D.L., Bennett, L.L., Grodsky, G.M.: Dynamics of insulin secretion by the perfused rat pancreas. Endocrinology 83, 572-584 (1968)

9. Grodsky, G.M.: A threshold distribution hypothesis for packet storage of insulin and its mathematical modeling. J. clin. Invest. 51, 2047-2059 (1972)

10. Gerritsen, G.C., Blanks, M.C.: Characterization of Chinese hamsters by metabolic balance, glucose tolerance and insulin secretion. Diabetologia 10, 493-499 (1974)

11. Gerritsen, G.C., Johnson, M. A., Schultz, J.R., Dulin, W.E., Soret, M. G.: Epidemiology of Chinese hamsters and preliminary evidence for genetic heterogeneity of diabetes. Diabetologia 581 - 588 (1974)

12. Grodsky, G.M., Frankel, B., Rudnick, A., Schachter, J., Lee, J., Fanska, R., West, L.: Characteristies of M-variant encephalomyocarditis virus (EMC) in the chemically diabetic nonobese Chinese hamster. Proceedings, VIII Congress of the International Diabetes Federation, Brussels, 1973. Excerpta med. International Congress Series 312, 304-315 (1974)

1.3. Renold, A.E.: The pathogenesis of diabetes mellitus. Calif. Med. 112, 23-34 (1970)

14. Cerasi, E., Luft, R., Efendic, S. : Decreased sensitivity of the pancreatic beta cells to glucose in prediabetic and diabetic subjects. A dose-response study. Diabetes 21, 224-234 (1972)
15. Orci, L., Stauffacher, W., Dulin, W. E., Renold, A. E., Rouiller, Ch.: Ultrastructural changes in a-cells exposed to diabetic hyperglycemia. Observations made on pancreases of Chinese hamsters. Diabetologia 6, $199-206(1970)$

16. Cerasi, E., Luft, R.: The effect of an adenosine- $3^{\prime}$, $5^{\prime}$ 'monophosphate diesterase inhibitor (aminophylline) on the insulin response to glucose infusion in prediabetic and diabetic subjects. Horm. Metab. Res. 1, $162-168(1969)$

17. Braaten, J.T., Faloona, G.R., Unger, R.H.: The effect of insulin on the alpha-cell response to hyperglycemia in long-standing alloxan diabetes. J. clin. Invest. 53, 1017-1021 (1974)

18. Gerich, J.E., Langlois, M., Noacco, C., Karam, J.H., Forsham, P.H.: Lack of glucagon response to hypoglycemia in diabetes: Evidence for an intrinsic pancreatic alpha cell defect. Science 182, 171-173 (1973)

19. Falconer, D. S.: Genetic aspects of breeding methods. In: The UFAW handbook on the care and management of laboratory animals, p. 72. Third ed., Baltimore: Williams and Wilkins 1966

20. Fajans, S.S., Floyd, J.C., Pek, S., Conn, J.W.: Studies on the natural history of asymptomatic diabetes in young peop e. Metabolism 22, 327-334 (1973)

21. Siperstein, M.D., Unger, R.H., Madison, L.L.: Studies of muscle capillary basement membranes in normal subjects, diabetic, and pre-diabetic patients. J. clin. Invest. 47, 1973-1999 (1968)

G. M. Grodsky, Ph.D.

Metabolic Research Unit

Dept. of Biochemistry

and Biophysics

University of California

San Francisco, Calif. 94143

USA 